\title{
Systemic Sclerosis and Pulmonary Arterial Hypertension: A Case Report
}

\author{
Ivana Aleksić ${ }^{1}$, Sandra Šarić ${ }^{1}$, Bojan Ilić ${ }^{1}$, Sonja Stojanovićn ${ }^{1,2}$, Marina Deljanin llićc, \\ Institute "Niška Banja", Niška Banja, Serbia \\ 2University of Niš, Faculty of Medicine, Niš, Serbia
}

\section{SUMMARY}

Pulmonary arterial hypertension (PAH), which occurs in about $15 \%$ of patients with systemic sclerosis (SSc), is a progressive vasculopathy and despite modern therapeutic options is still one of the leading causes of death in these patients.

We presented a patient diagnosed with the overlap syndrome (systemic sclerosis and rheumatoid arthritis) with a predominance of the clinical picture of systemic sclerosis (SSc), established in November 2018. She was initially treated by a rheumatologist with an antimalarial, which was soon discontinued by an ophthalmologist, followed by azathioprine which was excluded due to an allergic reaction. She has been continuously on corticosteroid therapy, and since January 2020, mycophenolate mofetil has been added to treatment. The patient was diagnosed with primary biliary cirrhosis by a gastroenterologist after clinical findings and additional examination methods; also, pulmonary fibrosis was diagnosed by a pulmonologist. In January 2020, deterioration of echocardiographic findings was registered (dilated right heart cavity, right ventricular systolic pressure (RVSP) $72 \mathrm{mmHg}$, tricuspid regurgitation 3+).

Sildenafil was proposed by a responsible cardiologist for therapy that was not approved by gastroenterologist. Due to worsening of her symptoms in the form of pronounced fatigue, shortness of breath, in August 2020, a cardiologist of the Institute "Niška Banja" started bosentan therapy in a dose of 2 $x 62.5 \mathrm{mg}$ per day. After the applied therapy, the patient had a subjective improvement and reduction of symptoms. In November 2020, a control echocardiographic examination registered a decrease in RVSP to $55 \mathrm{mmHg}$. In addition to the therapy proposed by the responsible rheumatologist (mycophenolate mofetil $2 \mathrm{~g}$ daily, prednisolone $15-20 \mathrm{mg}$ daily), the therapy prescribed by her cardiologist was also continued (bosentan $62.5 \mathrm{mg} 2 \times 1$ ), with regular controls and monitoring of laboratory analyses.

PAH in patients with SSc has a worse prognosis than idiopathic PAH, and additionally depends on RVSP and functional class. The process of treating PAH in patients with SSc requires a complex strategy that includes initial assessment of disease severity and subsequent responses to the therapy.

Key words: systemic sclerosis, pulmonary arterial hypertension, therapy

Corresponding author:

Ivana Aleksić

e-mail: i.aleksic@hotmail.com 


\section{INTRODUCTION}

Pulmonary arterial hypertension (PAH) has been defined as an increase in mean pulmonary arterial pressure $(\mathrm{mPAP}) \geq 25 \mathrm{mmHg}$ at rest, measured by right heart catheterisation (RHC). Recent data have shown that the normal value of mPAP at rest was $14.0 \pm 3.3 \mathrm{mmHg}$ with an upper limit of 20 $\mathrm{mmHg}$. The clinical significance of mPAP values between 21 and $24 \mathrm{mmHg}$ is still the subject of interpretation $(1,2)$.

Transthoracic doppler echocardiography should always be performed if PAH is suspected, and screening for the presence of PAH is recommended. Pulmonary artery systolic pressure can be noninvasively assessed by using Doppler techniques and when an acceptable tricuspid regurgitation jet is obtained, these assessments show an excellent overall correlation with invasively determined pulmonary artery systolic pressure. However, the estimated standard is relatively large (5 to $8 \mathrm{~mm} \mathrm{Hg})(2$, $3)$. Other echocardiographic findings include the right ventricle enlargement, paradoxical movement of the interventricular septum, and tricuspid insufficiency. Pericardial effusions can also be visualized in the absence of connective tissue disease, correlated with increased pressure in the right atrium (4). When considering PAH treatment, echocardiography alone is not enough to bring a decision, so it is necessary to carry out the catheterization.

The clinical classification of $\mathrm{PH}$ is intended to categorize different clinical conditions into five groups according to the similarity of their clinical presentation, pathophysiological and haemodynamic characteristics, and treatment strategy. Group 1 is called pulmonary arterial hypertension (PAH is a clinically progressive disease that can lead to the right heart failure and death). PAH can be idiopathic, hereditary, or a systemic connective tissueassociated disease (SCTD), most commonly with systemic sclerosis (SSc), then systemic lupus erythematosus (SLE) and mixed connective tissue disease (MCTD) (5).

The symptoms of PAH are not specific and are mainly a consequence of progressive right ventricular dysfunction. The initial symptoms typically occur with exertion. They include shortness of breath, exhaustion, weakness, anginal discomfort and fainting. Symptoms like dry cough, nausea and vomiting caused by exertion are less common. If symptoms occur at resting it means that the disease has progressed. Abdominal distension and leg swelling increase with the progression of right ventricle failure. The manifestation of PAH can be determined by the diseases that caused it or that are associated with PAH as well as any other diseases (6).

Patients with PAH usually have mild to moderately reduced lung volumes depending on the severity of the disease. Although diffusing capacity may be normal in $\mathrm{PAH}$, most patients have a reduced pulmonary diffusing capacity for carbon monoxide (DLCO). Low DLCO defined as $<45 \%$ of predicted value is associated with poor outcome. The differential diagnosis of low DLCO in PAH includes COPD, PAH associated with SSc, and parenchymal lung disease (7).

Therapy for PAH patients has progressed gradually over the past decade and has become more complex and effective. The treatment process entails a complex strategy that includes an initial assessment of the severity of the disease and the monitoring of consequent responses to the prescribed therapy. The initial approach includes general measures as well as supportive therapy. The second step involves treatment with approved PAH drugs according to a prognostic risk, recommendation level, and level of evidence. The third component refers to the initial treatment strategy response; in case of an inadequate response, a combination of approved drugs and transplants is proposed (5). In patients with $\mathrm{PAH}$, activation of the endothelin system in plasma and lungs has been manifested. Although it is unclear whether an increase of plasma endothelin-1 level is the cause or the consequence of $\mathrm{PAH}$, these data support a significant role of the endothelin system in the pathogenesis of PAH. Endothelin receptor antagonists (bosentan, ambrisentan) have found their place in therapeutic strategies. Also, since the pulmonary vascular network contains a significant amount of phosphodiesterase type 5, the potential clinical benefit of using phosphodiesterase type 5 inhibitors (PDE-5is) was examined in PAH. PDE-5is shows antiproliferative effects as well. Drugs used: sildenafil, tadalafil, and vardenafil lead to a significant pulmonary vasodilation, with a maximum effect after 60, 75 - 90, and 40 - 45 minutes $(8,9)$. In patients with $\mathrm{PAH}$, there is dysregulation of the metabolic pathway of prostacyclin, which is manifested by a decrease in the expression of prostacyclin synthase in the pulmonary arteries and prostacyclin urinary metabolites (9). Prostacyclin is produced primarily 
by endothelin cells and it is responsible for the potent vasodilator activity in the entire vascular network. Also, it is the most powerful endogenous inhibitor of platelet aggregation and has both antiproliferative and cytoprotective effects (10).

SSc is a chronic, systemic, autoimmune disease of unknown pathogenesis, characterized by the excessive production of fibers of the extracellular matrix, their accumulation in the vascular wall, skin and internal organs, which leads to fibrosis of the skin and internal organs, with simultaneous activation of the immune system that participates in damaging blood vessels of the skin and organs (11, 12).

SSc most commonly occurs between 30-50 years of age. This disease is found to be $3-4$ times more prevalent in women than men. The basis of scleroderma is vascular damage and activation of fibroblasts. Early vascular lesions involve small arteries, arterioles, and capillaries. Cytokines (including endothelin-1) are released in this initial endothelial dysfunction, causing vasoconstriction (13).

PAH occurs in about $15 \%$ of patients with SSc, it is a progressive vasculopathy and despite modern therapeutic options one of the leading causes of death in these patients $(14,15,16)$. Although the recommendations are clear and define the need for bi-annual echocardiographic examination, RHC is still the "gold standard" for assessing and confirming high PAP, as well as for assessing the severity of haemodynamic damage $(17,18)$.

\section{CASE REPORT}

The patient, born in 1946, was referred by the specialist rheumatology out-patient clinic at the
"Niška Banja" Institute to cardiovascular examination in the Institute, due to problems with severe suffocation, fatigue, and elevated values of RVSP.

This patient developed first symptoms in July 2018, like pain and swelling of the small joints of the hands, wrists joints and knee joints; the pain was nocturnal, followed by morning stiffness lasting one hour. The patient was treated at her hometown by a general practitioner who administered parenteral corticosteroids (CS) and non-steroidal anti-inflammatory drugs (NSAIDs) which provided a shortterm improvement. After three months, from October 2018, she reported the appearance of redness, fingers turning blue and pale when exposed to cold; a feeling of tightening and hardening of skin on face and hands, difficulty swallowing solids and severe fatigue as well. The patient was first examined by the consultant rheumatologist at the "Niška Banja" Institute during November 2018. The examination was based on the clinical assessment, laboratory and immunological analyses $(\mathrm{ESR}=60, \mathrm{CRP}=18, \mathrm{RF}=$ 384 , anti-CCP $=20$, positive ANA and anti-centromere antibodies - ACAs) and additional diagnostic methods (positive capillaroscopic finding, performed radiography of the hands and feet (Figure 1, 2 ), registered synovitis of the wrists on ultrasound examination, reduced DLCO $=41 \%$, diffusion coefficient $(\mathrm{KCO})=49 \%$, and the diagnosis of overlap syndrome was made (systemic sclerosis and seropositive rheumatoid arthritis) with a predominance of the clinical manifestations of SSC. Then, therapy with antimalarial (hydroxychloroquine $2 \times 200 \mathrm{mg}$ ) with CS, acetylsalicylic acid $100 \mathrm{mg}$, amlodipine 5 $\mathrm{mg}$ was initiated. After two months, the antimalarial was discontinued by a qualified ophthalmologist.

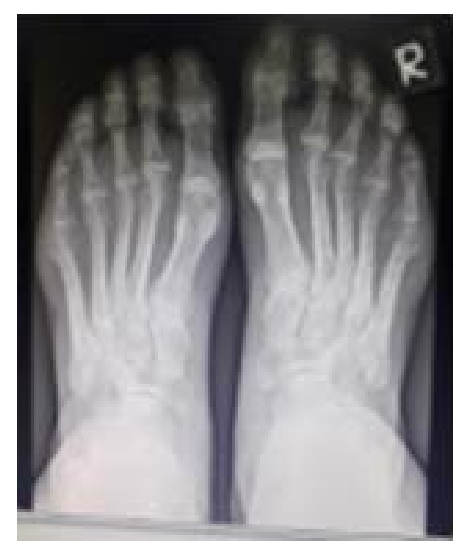

Figure 2. Feet radiography

Figure 1. Hands radiography 
In April 2019, she was hospitalized at the Clinic for Rheumatology of the Institute, where the diagnosis was confirmed based on clinical findings and additional testing methods and then azathioprine 2 × $50 \mathrm{mg}$ was introduced into her therapy. Elevated markers of liver enzymes $(\mathrm{ALT}=76, \mathrm{AST}=$ 57, GGT $=314, \mathrm{LDH}=406)$ and positive antimitochondrial antibodies were registered, which was the reason for referring her to gastroenterologist. Liver biopsy was performed, primary biliary cirrhosis diagnosis was established, and medications (hepatoprotectives) were prescribed. Also, she was examined by a pulmonologist and chest radiography

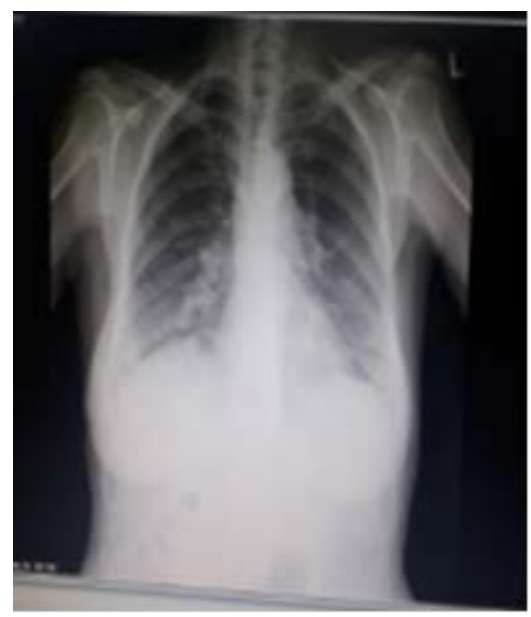

Figure 3. Lung radiography

In June 2019, the patient had allergic reaction on skin and oral cavity to azathioprine therapy. This was the reason to exclude azathioprine from the treatment plan, and only CS therapy (prednisolone 15 to $20 \mathrm{mg}$ per day) was continued. Subsequently, the patient did not have any significant deterioration of problems until November/December 2019. Then, during the examination, she stated that she was experiencing excessive exhaustion, shortness of breath, pain, as well as swelling of small joints of her fingers. Spirometry was performed, which showed deterioration compared to the results from April 2019 (DLCO $=34 \%$ ). Due to such results, hospital treatment was indicated to decide about the introduction of a disease-modifying drug.

In January 2020, she was hospitalized at the Clinic for Rheumatology of the Institute, and due to the deterioration of the disease, it was recommended that mycophenolate mofetil be included in her therapy with a dose of $1 \mathrm{~g}$ per day. Then, after echocardi- was performed (Figure 3) as well as lung MSCT (fibrous changes of the lungs in the lateral zones with honeycomb altered parenchyma in the lower lobes; micronodular changes on both sides) and pulmonary fibrosis diagnosis was made. Compression fracture of the L1 vertebra was verified on radiography of the lumbosacral part of the spine (Figure 4) and osteodensitometry showed the reduced values of bone mineral density: dg generalized osteoporosis (treated with vitamin D supplements along with bisphosphonates). Echocardiographic examination was performed during hospital treatment, RVSP $=32 \mathrm{mmHg}$.

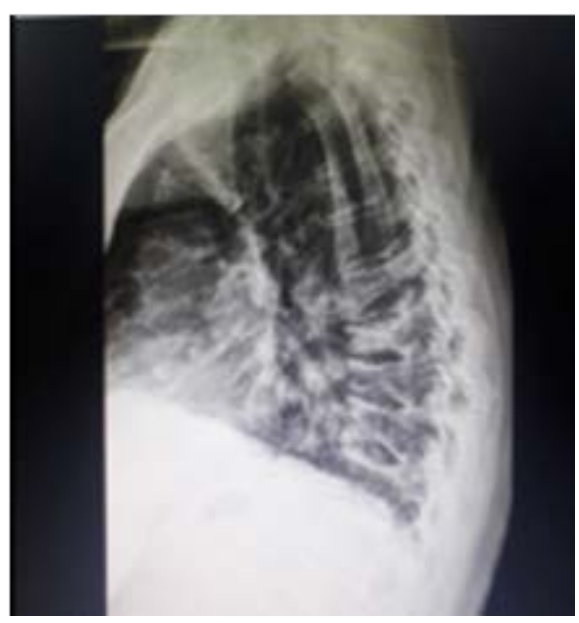

Figure 4. Radiography of Th-L spine

ographic examination, the deterioration was verified compared to previous results (right heart cavity dilated, RVSP $=72 \mathrm{~mm}$, tricuspid regurgitation $3+$ ). A cardiologist was consulted and sildenafil $20 \mathrm{mg} 2$ $x 1$ therapy was suggested due to pulmonary hypertension. The patient started mycophenolate therapy, but the proposed sildenafil was not approved by the gastroenterologist because of the presence of primary biliary cirrhosis. Right catheterization of the heart was also considered, but due to the current epidemiological situation caused by COVID-19, this could not be scheduled. In the further course of treatment, the patient reported the improvement related to her peripheral joints, reduced tightening of skin on hands and face, without fingertip ulcers.

On August 10, 2020, at the time of the scheduled check-up with the treating rheumatologist, the patient reported extreme fatigue, suffocation, exhaustion, poor tolerance to exertion (could only make 10 steps), lower legs swelling, without anginal 
problems. The patient was urgently referred to a cardiologist at the "Niška Banja" Institute. During the examination, the following was ascertained: mildly dyspneic, tachypneic; bilateral basal crepitations on the lungs; rhythmic action of the heart, systolic murmur at the top and at the Erb's point, AT 150/100 mmHg, HR 90 bpm. The hypertension represents one of the risk factors for cardiovascular disease (the last five years, maximum 220/100 mm $\mathrm{Hg})$ as well as hyperlipidemia. During the examination, an ECG was performed where sinus rhythm was registered as well as complete right bundle branch block, HR 90 bpm. Having read the medical records (hepatogram was normal), functionally WHO II-III class, CHILD-Pugh score A, it was decided to introduce bosentan in the therapy in a dose of $62.5 \mathrm{mg} 2 \times 1$ per day with a scheduled follow-up for a month with repeating laboratory tests (Table 1). After one-month therapy, during the follow-up ex- amination, the patient reported a significant subjective improvement, reduction of discomfort, and preserved functional capacity; the laboratory tests verified the preserved liver function (AST, ALT, GGT, bilirubin within the reference range, INR normal), so the continuation of the current therapy was advised.

In the period from November 9 to November 17, 2020, she was hospitalized at the Clinic for Rheumatology of the Institute. An echocardiographic examination was performed, and it revealed a significant decrease in right ventricular pressure (RVSP $=55 \mathrm{mmHg}$ ), tricuspid regurgitation grade of 2 - $3+$, right ventricular cavities normal. It was advised to increase the dose of mycophenolate to $2 \mathrm{~g}$ per day with the continuation of the previous therapy.

The discharge therapy list: tbl. mycophenolate mofetil $2 \mathrm{~g}$ daily; tbl. prednisone 15 - $20 \mathrm{mg}$ daily (af-

Table 1. Recommendations for effective monotherapy in the treatment of pulmonary arterial hypertension (group 1) according to the World Health Organization functional class

\begin{tabular}{|c|c|c|c|c|c|c|c|c|}
\hline \multirow{2}{*}{\multicolumn{3}{|c|}{ Medications }} & \multicolumn{6}{|c|}{ Class $^{\mathrm{a}}-$ Level $^{\mathrm{b}}$} \\
\hline & & & \multicolumn{2}{|c|}{ WHO -FC III } & \multicolumn{2}{|c|}{ WHO -FC IV } & \multirow[b]{2}{*}{-} & \multirow[b]{2}{*}{ - } \\
\hline \multicolumn{3}{|l|}{ Calcium channel blockers } & $\mathrm{I}$ & $\mathrm{Cd}^{\mathrm{d}}$ & $\mathrm{I}$ & C & & \\
\hline \multirow{3}{*}{$\begin{array}{l}\text { Endothelin receptor } \\
\text { antagonists }\end{array}$} & \multicolumn{2}{|l|}{ Ambrisentan } & $\mathrm{I}$ & $\mathrm{A}$ & $\mathrm{I}$ & $\mathrm{A}$ & $\mathrm{IIb}$ & $\mathrm{C}$ \\
\hline & \multicolumn{2}{|l|}{ Bosentan } & $\mathrm{I}$ & $\mathrm{A}$ & $\mathrm{I}$ & $\mathrm{A}$ & $\mathrm{IIb}$ & $\mathrm{C}$ \\
\hline & \multicolumn{2}{|l|}{ Macitentane } & $\mathrm{I}$ & $\mathrm{B}$ & $\mathrm{I}$ & $\mathrm{B}$ & $\mathrm{IIb}$ & $\mathrm{C}$ \\
\hline \multirow{3}{*}{$\begin{array}{l}\text { Phosphodiesterase type } 5 \\
\text { inhibitors }\end{array}$} & \multicolumn{2}{|l|}{ Sildenafil } & $\mathrm{I}$ & $\mathrm{A}$ & $\mathrm{I}$ & $\mathrm{A}$ & $\mathrm{IIb}$ & $\mathrm{C}$ \\
\hline & \multicolumn{2}{|l|}{ Tadalafil } & $\mathrm{I}$ & $\mathrm{B}$ & $\mathrm{I}$ & $\mathrm{B}$ & $\mathrm{IIb}$ & $\mathrm{C}$ \\
\hline & \multicolumn{2}{|l|}{ Vardenafils } & $\mathrm{IIb}$ & $\mathrm{B}$ & $\mathrm{IIb}$ & $\mathrm{B}$ & $\mathrm{IIb}$ & $\mathrm{C}$ \\
\hline Guanylate cyclase stimulators & \multicolumn{2}{|l|}{ Riociguat } & $\mathrm{I}$ & $\mathrm{B}$ & $\mathrm{I}$ & $\mathrm{B}$ & $\mathrm{IIb}$ & $\mathrm{C}$ \\
\hline \multirow{8}{*}{ Prostacyclin analogs } & Epoprostenol & Intravenouse & - & - & $\mathrm{I}$ & $\mathrm{A}$ & $\mathrm{I}$ & A \\
\hline & \multirow{2}{*}{ Iloprost } & Inhaled & - & - & $\mathrm{I}$ & $\mathrm{B}$ & $\mathrm{IIb}$ & $\mathrm{C}$ \\
\hline & & Intravenousg & - & - & IIa & $\mathrm{C}$ & $\mathrm{IIb}$ & $\mathrm{C}$ \\
\hline & \multirow{4}{*}{ Treprostinil } & Subcutaneous & - & - & $\mathrm{I}$ & $\mathrm{B}$ & $\mathrm{IIb}$ & $\mathrm{C}$ \\
\hline & & Inhaledg & - & - & $\mathrm{I}$ & $\mathrm{B}$ & $\mathrm{IIb}$ & $\mathrm{C}$ \\
\hline & & Intravenous $^{\mathrm{f}}$ & - & - & IIa & $\mathrm{C}$ & $\mathrm{IIb}$ & $\mathrm{C}$ \\
\hline & & Orals & - & - & $\mathrm{IIb}$ & $\mathrm{B}$ & - & - \\
\hline & \multicolumn{2}{|l|}{ Beraprostg } & - & - & $\mathrm{IIb}$ & $\mathrm{B}$ & - & - \\
\hline IP receptor agonists & \multicolumn{2}{|c|}{ Seleksipag (oral)g } & I & B & I & $\mathrm{B}$ & - & - \\
\hline
\end{tabular}

ter breakfast); tbl. pantoprazol $40 \mathrm{mg}$; tbl. alendronic acid $70 \mathrm{mg} / \mathrm{cholecalciferol} 5600 \mathrm{IU} 1 \times$ per week; drag. alphacalcidole $1 \mathrm{mcg}$ daily; tbl. bosentan 62.5 mg $2 \times 1$; tbl. amlodipine $5 \mathrm{mg}$; tbl. acetylsalicylic acid $100 \mathrm{mg}$; tbl. bisoprolol 5mg; tbl. perindopril 5 $\mathrm{mg}$ in the morning; tbl. furosemide $40 \mathrm{mg} 1+1+0$; tbl. Spironolactone $25 \mathrm{mg}$; tbl. pravastatin $20 \mathrm{mg}$ in the evening; hepatoprotective therapy; hygienic dietary regime.

At the medical checkup conducted on February 22,2021 , the patient stated a subjective improvement concerning the applied therapeutic protocol, 
reduced pain and swelling in the peripheral joints, improved effort tolerance, reduced fatigue; laboratory test results confirmed a subtle inflammatory syndrome, blood counts within the reference values, normal values of liver enzymes and nitrogen products. Due to the exacerbation of lung function and further reduction of DLCO $=29 \%$ and $\mathrm{KCO}=47 \%$ with preserved lung ventilation, a consultation of the pulmonologists from the Clinical Centre Niš was scheduled for March 2021. A follow-up examination by the rheumatologist and cardiologist was scheduled within one month, with repeated laboratory analyses.

\section{DISCUSSION}

PAH is a clinical syndrome that includes various diseases which cause increased blood pressure in the pulmonary artery and right heart failure. Vascular remodeling dominates in SSc/PAH as a result of inflammation and endothelial damage. Endothelial hyperplasia, hypertrophy of media and thickening of adventitia may occur. In SSc, the prevalence varies between $8 \%$ and $12 \%$, and about $30 \%$ of deaths in this group of patients are due to $\mathrm{PAH}$. Since SCTDs/PAH is most common in patients with SSc, the European Society of Cardiology and the European Respiratory Society (ESC/ERS) has recommended that all patients with scleroderma and those with SCTDs and scleroderma-like characteristics should be included in annual echocardiographic screening for referrals to right heart catheterization, even without the presence of clinical symptoms (12, 18). A large international multicentre cross-sectional study - DETECT (Evidence-based Detection of Pulmonary Arterial Hypertension in Systemic Sclerosis) helped in generating an algorithm for screening patients for the presence of PAH which is nowadays recommended for all patients with SSc (19). The study included 466 patients from 62 centers in North America, Europe and Asia, who had an increased risk of PAH ( $>3$ years from the SSc diagnosis, with DLCO $<60 \%$ ) and who underwent the right heart catheterization in which PAH prevalence of $19 \%$ was found. Commonly, SSc/PAH is considered as a late manifestation of SSc and it is more prevalent in patients with a limited form of the disease. Risk factors for the development of SSc/PAH are age, affected skin degree, severe peripheral vascular disease, presence of pulmonary fibrosis, gastroesophageal reflux and dysphagia (19).

The endothelin, NO, and prostacyclin pathways are well-known pathophysiological mechanisms that participate in the development and progression of $\mathrm{PAH}$. Clinical practice has established the use of ERA, PDE-5i and prostanoids as the therapeutic modalities that target three separate path signals that are the basis of PAH $(12,15)$.

Specific PAH therapy is focused on reducing the pressure in the pulmonary circulation and can significantly improve the symptoms and upgrade the quality of life and survival. The effect of treatment is now improved also by combinations of $2-3$ PAH-specific drugs (15). Doppler echocardiography is indispensable in everyday clinical practice. This method evaluates the function of the right ventricle, the value of RVSP, and ventricular dilatation, which serves not only as a confirmation of $\mathrm{PAH}$, but also as the means to evaluate the effect of the selected therapeutic modality (4). However, the prognosis of PAH in patients with SCTDs is still less favorable in comparison to patients with other forms of PAH. With adequate therapy, the reported one-year mortality is $15 \%$. According to the latest data, the fiveyear survival rate in $\mathrm{PAH}$ patients after lung transplantation is $50-75 \%$, and ten-year survival is 45 $66 \%$ with preserved quality of life (20).

\section{CONCLUSION}

Pulmonary arterial hypertension in patients with SSc has a worse prognosis than idiopathic PAH and it additionally depends on RVSP and the WHO functional class. In untreated patients, mortality is very high (one-year mortality rate being $38 \%$ ).

Our case report confirmed that the process of treating PAH in patients with SSc is a complex strategy that includes an initial assessment of the severity of the disease and subsequent responses to the therapy. 


\section{References}

1. Stamenković B. Najnovije EULAR preporuke za lečenje sistemske skleroze. Zapaljenske reumatske bolesti. Balneoclimatologia 2018;42(1): 125-30.

2. Berger M., Haimowitz A., Van Tosh A., et al. Quantitative assessment of pulmonary hypertension in patients with tricuspid regurgitation using continuous wave Doppler ultrasound. J Am Coll Cardiol 1985; 6: 359. https://doi.org/10.1016/S0735-1097(85)80172-8

3. Currie P.J., Seward J.B., Chan K.L. et al.: Continuous wave Doppler determination of right ventricular pressure: a simultaneous Dopplercatheterization study in 127 patients. J Am Coll Cardiol 1985; 6: 750.

https://doi.org/10.1016/S0735-1097(85)80477-0

4. Hinderliter A.L., Willis P.W., Long W.et al.: Frequency and prognostic significance of pericardial effusion in primary pulmonary hypertension: PPH Study Group. Primary pulmonary hypertension. Am J Cardiol 1999; 84: 481.

https://doi.org/10.1016/S0002-9149(99)00342-2

5. Galiè N, Humbert M, Vachiery JL, et al. 2015 ESC/ERS Guidelines for the diagnosis and treatment of pulmonary hypertension. Eur Heart J 2016;37(1):67-119.

https://doi.org/10.1093/eurheartj/ehv317

6. Humbert M, Galiè N, McLaughlin VV, et al. An insider view on the World Symposium on Pulmonary Hypertension. Lancet Respir Med. 2019;7(6):484-5.

https://doi.org/10.1016/S2213-2600(19)30111-0

7. Hansen JE, Oudiz RJ, Wasserman K. Pulmonary function in primary pulmonary hypertension. J Am Coll Cardiol 2003;41:1028-35. https://doi.org/10.1016/S0735-1097(02)02964-9
8. Taichman DB, Ornelas J, Chung L, et al. Pharmacologic Therapy for Pulmonary Arterial Hypertension in Adults: CHEST Guideline and Expert Panel Report. Chest 2014;146(2):449-75. https://doi.org/10.1378/chest.14-0793

9. Galiè N, Manes A, Branzi A. Prostanoids for pulmonary arterial hypertension. Am J Respir Med 2003;2:123-37.

https://doi.org/10.1007/BF03256644

10. Jones DA, Benjamin CW, Linseman DA. Activation of thromboxane and prostacyclin receptors elicits opposing effects on vascular smooth muscle cell growth and mitogen-activated protein kinase signaling cascades. Mol Pharmacol 1995;48: 890-6.

11. LeRoy EC, Black C, Fleischmajer R, et al. Scleroderma (systemic sclerosis): Classification, subsets and pathogenesis J Rheumatol 1988;15:202-5.

12. Aleksić I, Stamenkovic B, Milenkovic S, et al. Artritis u sistemskoj sklerozi-prikaz slucaja Hronični artritisi 2016. Balneoclimatologia 2016;40(1): 213-9.

13. Damjanov N. Sistemska skleroza: klinički oblici i rana dijagnoza bolesti. Acta Rheum Belgrad 2005 (2);131-5.

14. Marina Deljanin Ilić. Ehokardiografija u dijagnostici plućne hipertenzije.

Balneoclimatologia 2017;41(1):229-38.

15. Šarić S, Stamenković B, Aleksić I, et al. Značaj evaluacije poremećaja plućne funkcije $u$ sistemskoj sklerozi-prikaz slučaja. Hronični artritisi 2016. Balneoclimatologia 2016;40(1): 221-7.

16. Le Pavec J, Humbert M, Mouthon L, et al. 
Systemic sclerosis-associated pulmonary arterial hypertension. Am J Respir Crit Care Med 2010;181(12):1285-93.

https://doi.org/10.1164/rccm.200909-1331PP

17. Denton $\mathrm{CP}$, Pope JE, Peter $\mathrm{HH}$, et al. (Long-term effects of bosentan on quality of life, survival, safety and tolerability in pulmonary arterial hypertension related to connective tissue diseasesAnn Rheum Dis 2008; 67: 1222-8. https://doi.org/10.1136/ard.2007.079921

18. Aithala R, Alex AG, Danda D. Pulmonary hypertension in connective tissue diseases: an update. Int J Rheum Dis. 2017;20(1):5-24.
https://doi.org/10.1111/1756-185X.13001

19. Coghlan JG, Denton CP, Grunig E, et al, DETECT study group: Evidence-based detection of pulmonary arterial hypertension in systemic sclerosis: The DETECT study. Ann Rheum Dis 2014;73(7):1340-9.

https://doi.org/10.1136/annrheumdis-2013-203301

20. Kato M, Atsumi T. Pulmonary arterial hypertension associated with connective tissue diseases: A review focusing on distinctive clinical aspects. Eur J Clin Invest 2018;48:e12876.

https://doi.org/10.1111/eci.12876 


\title{
Prikaz bolesnika sa sistemskom sklerozom i plućnom arterijskom hipertenzijom
}

\author{
Ivana Aleksić ${ }^{1}$, Sandra Šarić1, Bojan Ilić1, Sonja Stojanović1,2, Marina Deljanin llić1,2 \\ ${ }^{1}$ Institut "Niška Banja", Niška Banja, Srbija \\ 2Univerzitet u Nišu, Medicinski fakultet, Niš, Srbija
}

\section{S AŽETAK}

Plućna arterijska hipertenzija (PAH) javlja se u oko 15\% bolesnika sa sistemskom sklerozom (SSc) i predstavlja progresivnu vaskulopatiju, te je uprkos savremenim terapijskim mogućnostima jedan od vodećih uzroka smrti kod ovih bolesnika.

U ovom radu prikazali smo bolesnicu kojoj je dijagnoza overlap sindroma (sistemska skleroza i reumatoidni artritis) sa predominacijom kliničke slike SSc postavljena novembra 2018.godine. Od strane reumatologa lečena je u početku antimalarikom, koji je ubrzo isključen od strane oftalmologa; nakon toga azatioprinom koji je isključen zbog alergijske reakcije. Sve vreme je na kortikosteroidnoj terapiji, a od januara 2020. godine u terapiju je uveden i mikofenolat mofetil. Kod bolesnice je od strane gastroenterologa nakon kliničkog nalaza $i$ uradjenih dopunskih metoda ispitivanja postavljena dijagnoza primarne bilijarne ciroze; od strane pulmologa fibroza pluća. Januara 2020. godine kod nje je registrovano pogoršanje ehokardiografskog nalaza (dilatirane desne srčane šupljine, sistolni pritisak u desnoj komori (SPDK) 72 $\mathrm{mmHg}$, trikuspidalna regurgitacija 3+). Od strane nadležnog kardiologa predložen sildenafil u terapiji koji nije odobren od strane gastroenterologa. Zbog pogoršanja tegoba u vidu izraženog zamora, osećaja nedostatka vazduha, gušenja, avgusta 2020. godine od strane kardiologa Instituta "Niška Banja“ započeta je terapija bosentanom u dozi od $2 \times 62,5 \mathrm{mg}$ dnevno. Nakon primenjene terapije, kod bolesnice dolazi do subjektivnog poboljšanja i smanjenja tegoba. Novembra 2020. godine na kontrolnom ehokardiografskom pregledu registruje se smanjenje SPDK na $55 \mathrm{mmHg}$. Uz terapiju nadležnog reumatologa (mikofenolat mofetil $2 \mathrm{~g}$ denvno, prednisolon 15 - $20 \mathrm{mg}$ dnevno) nastavljena je i terapija od strane nadležnog kardiologa (bosentan 62,5 mg $2 \times 1$ ) uz zakazane redovne kontrole i redovni monitoring laboratorijskih analiza.

Zaključili smo da PAH kod bolesnika sa SSc ima lošiju prognozu od idiopatske PAH, a dodatno zavisi i od pritiska u desnoj komori i funkcionalne klase. Proces lečenja PAH kod bolesnika sa SSc je kompleksna strategija koja uključuje inicijalnu procenu težine bolesti i kontinuiranu procenu odgovora na terapiju.

Ključne reči: sistemska skleroza, plućna arterijska hipertenzija, terapija 